\title{
Kjønnsforskjeller i forekomst av legemiddelrelaterte bivirkninger
}

\author{
Hedvig Nordeng \\ Institutt for farmakoterapi, Universitetet i Oslo, Postboks 1065 Blindern, 0316 Oslo
}

\begin{abstract}
SAMMENDRAG
Kvinnelig kjønn er blitt identifisert som risikofaktor for legemiddelrelaterte bivirkninger både i primærhelsetjenesten og under sykehusopphold. Hyppigere forekomst av bivirkninger kan forklares delvis, men ikke fullstendig, av at kvinner som gruppe konsumerer oftere og flere legemidler. Videre har legemiddelbruk hos kvinner i mange tilfeller tilknytning til biologiske tilstander som menstruasjon, graviditet og menopause, og den øker med alderen. Det er viktig å ta i betraktning kulturelle forskjeller hos kvinner og menn som kan være med på å overestimere kjønnsforskjellene i bivirkningsforekomsten. Kvinner bruker helsevesenet hyppigere og rapporterer oftere bivirkninger. Høyere bivirkningsfrekvens hos kvinner kan også være resultat av at kvinner generelt får høyere dose per kg enn menn fordi kvinner veier mindre. Kjønnsforskjeller i bivirkninger kan i tillegg være knyttet til forskjellig aktivitet i leverenzymene cytochrom P450, som metaboliserer de fleste legemidler. Strukturelle og funksjonelle kjønnsforskjeller finnes også i nyrer, lunger, hjerte/kar- og mage/tarmsystemet, og påvirker i varierende grad effekt og sikkerhet av legemidler.
\end{abstract}

\section{Nordeng H. Gender differences in the occurrence of adverse drug events.} Nor J Epidemiol 1999; 9 (2): 143-148.

\section{ENGLISH SUMMARY}

Both pharmacoepidemiological and clinical studies have identified female gender as a risk factor for adverse events of drugs, both in primary care and in a hospital setting. Frequent occurrence of adverse events can partly, but not totally, be explained by the fact that women as a group consume more drugs than men. Women's drug consumption can to a certain degree be related to menstruation, pregnancy and menopause, and increases with age. It is essential to take into account cultural differences that can contribute to an overestimation of the gender effect of adverse drug events. Women use the health care system more frequently and report more often and more willingly adverse events. Higher frequency of adverse events may also be the result of women receiving higher dose per $\mathrm{kg}$ than men because women weigh less. Differences in activity of the liver enzyme system cytochrome P450 that metabolises most drugs may also cause gender differences in adverse drug events. There also exists structural and functional differences between women and men in the kidney, lung, cardiovascular and gastrointestinal system that may influence the effect and safety of drugs.

\section{INNLEDNING}

I farmakoepidemiologien interesserer man seg særlig for forskrivning og bruk av legemidler med fokus på de helsemessige, sosiale og økonomiske konsekvensene dette medfører. En viktig del av dette er overvåking av legemidlers sikkerhet, "pharmacovigilance" i engelsk språk. Bivirkninger er definert av Verdens Helseorganisasjon (WHO) som enhver skadelig, utilsiktet eller uønsket effekt av et legemiddel gitt i normale doser. Alvorlighetsgraden av bivirkninger strekker seg fra forbigående ubehag til dødelig utfall, og har betydelige konsekvenser både for enkeltindi- videt og for samfunnet i sin helhet. Kvinnelig kjønn som risikofaktor for bivirkninger har fått økende interesse de siste ti årene (1-3). Nå har også myndighetene i Norge og Sverige, ved utgivelsen av offentlige utredninger om kvinners helse, interessert seg for kvinners sikkerhet og bruk av legemidler (4-6). Denne artikkelen søker å belyse de forskjellige biologiske og psykososiale faktorer som kan øke kvinners risiko for å utvikle bivirkninger. Ved vurdering av forskjeller i bivirkningsfrevensen mellom kjønnene, må i tillegg ulikheter i legemiddelbruk, spontan bivirkningsrapportering, sykdomsprevalens, bruk av flere legemidler samtidig og alder tas i betraktning. 


\section{FOREKOMMER BIVIRKNINGER HYPPIGERE HOS KVINNER ENN HOS MENN?}

\section{Studier på kjonn som risikofaktorer for bivirkninger}

Risikofaktorer for legemiddelbivirkninger har vært studert både i sykehus, i primærhelsetjenesten, og ved bruk av myndighetenes og produsentenes bivirkningsdatabaser. Flere risikofaktorer er blitt identifisert fra studier i sykehusmiljøer, blant dem kjønn, alder, bruk av flere legemidler samtidig, tidligere bivirkninger, varighet av sykehusopphold og lever- og nyresykdom (7-9). I en ettårig prospektiv studie fra 1993-94 av forekomst av bivirkninger hos innlagte pasienter, var bivirkninger assosiert med alder over 65 år og kvinnelig kjønn. Relativ risiko for kvinner var 1,5 for å få en bivirkning. De vanligste bivirkningene var kvalme og oppkast, magesår og utslett, forårsaket hyppigst av acetylsalisylsyre, cyklofosfamid og digitoksin (10). I en metaanalyse var prevalensen av tardive dyskinesier etter antipsykotisk behandling signifikant høyere hos kvinner (27\%) enn hos menn (22\%) (11). Derimot ble det $\mathrm{i}$ en nylig publisert studie funnet at menn hadde oftere aggresjon og dyskinesier som bivirkning av SSRI enn kvinner, mens bivirkninger av SSRI som var vanligere hos kvinner var dermatologiske reaksjoner, tretthet, hyponatremi og hoste (12). I en engelsk studie på bivirkninger av nyere, reseptforskrevne preparater $i$ allmennpraksis, var antall bivirkninger signifikant høyere hos kvinner i alle aldre over 19 år. Den aldersjusterte relative risiko for bivirkninger for kvinner var 1,6 med 95\% konfidensintervall 1,5-1,7 (13). Myndighetenes bivirkningsovervåkning har til hensikt å fange opp signaler om ukjente bivirkninger som kan være hypotesegenererende, men kan ikke brukes til å regne ut insidensrater (14). Underrapportering av bivirkninger (15-17), spesielt av bivirkninger som er mindre alvorlige, og mangel på formelle kausalitetsvurderinger, er en begrensning for spontane bivirkningssystemer. I 1997 var 60\% av bivirkninger rapportert til Statens legemiddelkontroll opplevd av kvinnelige pasienter (18). Kjønnsforskjellen ble forklart med lavere underrapportering hos menn enn kvinner. En viktig metodologisk svakhet ved studier som bruker data fra spontane rapporteringssystemer, ligger i at kvinner er mer villige til å meddele problemer, slik som bivirkninger.

Få publiserte studier finner ingen relasjon mellom kvinnelig kjønn og bivirkninger. I en nylig publisert studie ble det ikke funnet kjønnsforskjell eller aldersforskjeller i innleggelsesrater ved sykehusets akuttmottak på grunn av legemiddelrelaterte bivirkninger, men flere kvinner enn menn oppsøkte akuttmottaket på grunn av bivirkninger (19). Resultater fra både farmakoepidemiologiske og kliniske studier tyder på at bivirkninger oppstår hyppigere hos kvinner $i$ både primarhelsetjeneste og under sykehusopphold. Arsakene til forskjellig forekomst av bivirkninger mellom kvinner og menn kan skyldes biologiske forskjeller, forskjell i konsum, eller psykososiale forskjeller.

\section{Står mengden rapporterte bivirkninger i direkte relasjon til konsumet?}

Det er mulig at økt forekomst av bivirkninger hos kvinner står i direkte forhold til økt bruk av legemidler. Kjønnsspesifikk salgsstatistikk har vist at legemiddelbruk øker med alderen, og at kvinner som gruppe har høyere forbruk enn menn i alle aldersgrupper, unntatt de aller yngste $(20,21)$. Denne observasjonen er blitt gjort i praktisk talt alle studier der legemiddelbruk er blitt studert kjønnsspesifikt. I Sverige viser kjønnsspesifikk salgsstatistikk fra 1996 at menn bare ligger høyere i bruk av magesårmidler, antidiabetika, lipidsenkende midler og de nyere hjertemidlene (kalsiumantagonister og ACE-hemmere) (21). Mange årsaker til kvinners legemiddelbruk er blitt undersøkt (Tabell 1). Legemiddelbruk hos kvinner er vist å ha nær sammenheng med naturlige biologiske tilstander (22). Unge kvinner konfronteres med bruk av analgetika og jerntabletter allerede ved første menstruasjon, senere blir de oppfordret til å ta perorale antikonsepsjonsmidler. Tretti prosent av norske kvinner $\mathrm{i}$ aldersgruppen 15-45 år brukte peroral antikonsepsjon i 1986-87 (23), og fra 45-50 års alderen er det sterkt press i retning av østrogenbruk. Tromsøstudien viste at ca. $30 \%$ av alle kvinnene hadde brukt smertestillende midler, og at analgetikabruken delvis var knyttet til menstruasjonsplager (24). Både Tromsøog Finnmark-studien viste en signifikant kjønnsforskjell i legemiddelbruken etter justering for sykelighet og bruk av helsetjenester, og konkluderte med at legemiddelbruk avgjøres av behov (morbiditet), dernest av bruk av helsetjenester og livsstil. Sosiodemografiske faktorer hadde liten innflytelse på legemiddelbruken $(23,25)$. Kvinners høyere forbruk av psykofarmaka er godt dokumentert (23,26-28). I følge Norsk reseptstatistikk i 1996 representerte kvinner henholdsvis $79 \%$ og $70 \%$ av brukere av antidepressiva og anxiolytika (20). At kvinner lever lenger enn menn, bidrar til økt totalbruk. Kjønnsforskjeller i sykdomsprevalens vil kunne være med på å forklare kjønnsforskjeller i bruk av legemidler. Kvinner har høyere forekomst av enkelte sykdommer som hypotyrose (i aldersgruppen over 70 år er forekomsten $4 \%$ av

Tabell 1. Hypoteser om hvorfor kvinners legemiddelbruk er større enn menns.

\footnotetext{
Kvinner lever lenger enn menn

Kvinner har flere kroniske sykdommer enn menn

Kvinner har høyere morbiditet, men lavere mortalitet enn menn

Kvinner har et annet helsebehov knyttet til sin reproduktive rolle

Kvinner har annen sykdomsadferd

Kvinner har høyere legeforbruk

Kvinner har lavere toleranse for en del symptomer

Kvinner er mer villige til å spørre om legemidler

Kvinner prioriterer mer tid på helse

Menn underrapporterer sitt legemiddelbruk, især for psykofarmaka

Leger forskriver oftere og flere legemidler til kvinner
} 
befolkningen, $80 \%$ er kvinner), urinveisinfeksjoner (kvinner:menn; 9:1) og artrose (kvinner:menn; 7:1 hos premenstruelle kvinner og 3:1 hos postmenopausale kvinner) (29). Flere autoimmune sykdommer forekommer oftere hos kvinner enn menn, for eksempel systemisk lupus erytematosus (kvinner:menn; 9:1), Sjøgrens syndrom (kvinner:menn; 10:1) og multippel sklerose (kvinner:menn; 2:1) (30). Signifikante kjønnsforskjeller er blitt beskrevet for forekomsten av psykiske lidelser (31-33). Økt legemiddelkonsum hos kvinner ser ut til à vare tett knyttet til kvinners reproduktive rolle og lenger levealder (og dermed økt sykelighet), og vil i stor grad kunne forklare den økte forekomsten av bivirkninger hos kvinner.

\section{PSYKOSOSIALE ÅRSAKER TIL KJØNNSFOR- SKJELLER I KONSUM OG BIVIRKNINGER AV LEGEMIDLER}

\section{Forskjellig helsekultur og opplevelse av bivirkninger mellom menn og kvinner?}

Kvinner er vant til å ta seg av hele familiens helse og prioriterer mer tid til helse. Kvinner har generelt flere legebesøk (34) og flere legebesøk på grunn av psykiske plager enn menn (32). Kjønnsforskjeller finnes i kvinner og menns symptombeskrivelser (35). I intervjuundersøkelser kan selve intervjuformen føre til skjevhet i bivirkningsrapporteringen. Intervjuene blir oftere utført av kvinner, og dette kan medføre at kvinner lettere meddeler bivirkninger. I tillegg kan spørsmålene være utformet slik at kvinner finner det lettere å svare på dem. Menn underrapporterer bivirkninger (især ved bruk av psykofarmaka), muligens fordi de bagatelliserer sine symptomer. Disse faktorene kan fore til en overestimering av legemiddelbivirkninger hos kvinner og gjøre kjønnsforskjellen $i$ forekomst av bivirkninger feilaktig større.

\section{Kjønnsforskjeller relatert til forskrivningspraksis}

Kvinners sykdomsadferd er muligens forskjellig fra menns, idet kvinner er mer villige til å stille spørsmål om legemidler og har muligens lavere toleranse for en del symptomer. Studier på forskrivningspraksis i forhold til kjønn fastslår at kvinner, oftere enn menn, får resept etter en legekonsultasjon, selv etter å ha kontrollert for relevante faktorer som alder, alvorlighetsgrad, tilstedeværelse av skade, tidligere legebesøk og kroniske tilstander i forhold til akutte tilstander $(36,37)$. Dette vil føre til at kvinner konsumerer mer legemidler enn menn, og kan oppleve hyppigere bivirkninger. En studie av legens og pasientens kjønn på innflytelsen av psykofarmakaforskrivning viste at kvinnelige pasienter hadde signifikant høyere sannsynlighet for å få forskrevet psykofarmaka fra en kvinnelig lege enn en mannlig lege (38).

\section{BIOLOGISKE FORSKJELLER SOM ÅRSAK TIL KJØNNSFORSKJELLER I BIVIRKNINGS- FOREKOMSTER}

Tradisjonelt er kvinner blitt ekskludert fra kliniske studier, og dermed er resultater fra medisinsk forskning på menn blitt ekstrapolert til å gjelde for kvinner, uten en tilstrekkelig dokumentasjon på sikkerhet og anvendbarhet hos kvinner. Hvilke konsekvenser det har for kvinner i dag, er ukjent. Gis et legemiddel $\mathrm{i}$ for lav dose, vil optimal effekt av legemidlet ikke oppnås, og med for høy dose øker risikoen for bivirkninger. Økt risiko for bivirkninger er blitt knyttet til at kvinner gjennomgående får høyere dose per kg enn menn, fordi de har lavere kroppsvekt enn menn. Innen enkelte medisinske grener, for eksempel ved medikamentell kreftbehandling, tas pasientens vekt $\mathrm{i}$ betraktning. Flere forfattere belyser kjønnsforskjeller i bivirkningsfrekvens hovedsakelig via en biologisk modell $(2,39)$, og særlig er psykofarmaka blitt studert $(3,29)$. Strukturelle og funksjonelle kjønnsforskjeller i hjerte og kar, nyre, lever, lunge og mage/tarmsystemet $(30,40)$ påvirker i varierende grad effekt og sikkerhet av legemidler. En metaanalyse konkluderte med at kvinnelig kjønn var en signifikant risikofaktor for torsades de pointes etter bruk av kardiovaskulære legemidler, og at årsaken til dette lå i reelle kardiale elektrofysiologiske forskjeller mellom menn og kvinner (41). Kvinner hadde også høyere risiko for brå død under antiarrytmisk terapi (41). Kvinner har mindre produksjon av magesyre, og magesekken tømmes senere. Dette kan påvirke opptak av legemidler (42). En oversiktsartikkel konkluderer med at aktiviteten av leverenzymet CYP3A4 synes å være høyere hos kvinner enn hos menn, mens aktiviteten av de fleste andre leverenzymer involvert i legemiddelmetabolisering er høyest hos menn (Tabell 2) $(2,43)$. Kvinner vil således ha lavere serumkonsentrasjoner av legemidler som metaboliseres av CYP3A4, for eksempel midazolam (2,39). Metabolisering av teofyllin, som har et smalt terapeutisk konsentrasjonsområde, påvirkes både av kjønn, røyking og alder (2). Etter langtidsdosering kan fettløselige legemidler lagres i fettvevet og gi lengre halveringstider og forhøyede plasmakonsentrasjoner hos kvinner. Diazepam er eksempel på et slikt medikament. For å unngå bivirkninger, bør dosen tilpasses disse forholdene (39). Høyere plasmakonsentrasjoner hos kvinner enn hos menn sees ved sammenlignbare doser i mg/kg for antipsykotika tiotixen (uregistrert i Norge) og flufenazin (44).

Det er vel kjent at alder kan ha betydning for metabolisering og nedbrytning av legemidler. Siden eldre kvinner representerer en stor del av legemiddelbrukerne, er det viktig å ta i betraktning interaksjonen mellom alder og kjønn. Økende alder og kvinnelig kjønn var assosiert med høyere plasmanivåer av amitryptilin slik at forfatterne anbefalte dosereduksjon hos kvinner over 50 år (45). Aldersavhengig reduksjon 
Tabell 2. Sammenligning av aktivitet til cytokrom P450 (CYP) isoenzymer mellom kvinner og menn $(2,43)$.

\begin{tabular}{llccc}
\hline & & \multicolumn{3}{c}{ Aktivitet* } \\
\cline { 3 - 5 } System & Eksempel & $\mathrm{K}>\mathrm{M}$ & $\mathrm{K}<\mathrm{M}$ & $\mathrm{K}=\mathrm{M}$ \\
\hline CYP3A4 & erytromycin & $\mathrm{X}$ & & \\
midazolam & $\mathrm{X}$ & & \\
CYP2D6 & klomipramin & & & $?$ \\
CYP2C19 & omeprazol & & $?$ & \\
piroxicam & & $?$ & \\
CYP1A2 & koffein & & $\mathrm{X}$ & \\
Fluorouracil dehydrogenase & fluorouracil & & $\mathrm{X}$ & \\
Konjugering & paracetamol & & $\mathrm{X}$ & \\
N-acetyltransferase & koffein & & & $\mathrm{X}$ \\
Alkohol dehydrogenase & etanol & & $\mathrm{X}$ & \\
Renal sekresjon: & & & $\mathrm{X}$ \\
$\quad$ syrer & kloxacillin & & $\mathrm{X}$ & \\
baser & amantadin & & & \\
\hline
\end{tabular}

* $\mathrm{K}=$ kvinne, $\mathrm{M}=$ mann, ? = data er ikke overbevisende, men det kan se ut som om en sammenheng eksisterer.

i nedbrytning av alfentanil ble registrert for kvinner, men ikke for menn, i en studie på 36 pasienter (46).

I en studie på forhold mellom alder og nedbrytning av leverenzym CYP3A substrater (for eksempel midazolam, erytromycin og lidokain) ble det konkludert at CYP3A-enzymaktiviteten var upåvirket av alder i perioden 27-83 år, og at forandringer i blodgjennomstrømning av leveren og leverstørrelse, legemiddeldistribusjon og -binding var ansvarlig for den aldersrelaterte reduksjonen i nedbrytningen (47). I denne studien var CYP3A-aktiviteten $24 \%$ høyere hos kvinner enn hos menn $(p=0,027)$.

Graviditet kan innvirke på effekt og sikkerhet av legemidler (48). Ofte er plasmakonsentrasjoner lavere under graviditeten. Dette skyldes forandringer i farmakokinetiske prosesser som absorpsjon, distribusjon og eliminasjon. For antiepileptika synker serumkonsentrasjoner ved graviditet, og dette kan resultere i suboptimal kontroll av anfallshyppighet (49). På grunn av liten terapeutisk variasjonsbredde, har senkning i litiumkonsentrasjon i blodet resultert i svikt i antipsykotisk behandling (50). Østrogen, progesteron og testosteron kan ha betydning for forekomst av bivirkninger. Variasjon av østrogen og progesteron under kvinnens menstruasjonsyklus kan påvirke enzymaktiviteten, men har ikke gitt klinisk signifikante forskjeller i omsetning av legemidler (51). Hos kvinner er legemiddelinteraksjon med perorale antikonsepsjonsmidler eller hormonell erstatningsterapi svært aktuell. Alle antiepileptika, med unntak av valproat, reduserer sikkerheten av peroral antikonsepsjon. Dette kan føre til ikke planlagte graviditeter (52).

Kjønnsforskjeller i farmakodynamikk er lite utforsket hos mennesker. Noen få humane studier indikerer forskjeller i effekt av analgetika hos kvinner og menn. I en studie ble det vist at kvinner hadde mindre smerte- stillende virkning av ibuprofen, og at denne forskjellen ikke kunne tillegges farmakokinetiske forskjeller (53). Derimot ble det $\mathrm{i}$ en annen studie vist at opioider som virket på en bestemt type reseptorer (kappa) hadde bedre smertestillende effekt hos kvinner enn hos menn (54). Økt følsomhet hos kvinner for psykofarmaka og kardiovaskulære legemidler har vært foreslått som årsak til økt forekomst av bivirkninger hos kvinner $(29,41)$.

\section{KONKLUSJON}

Det er flere faktorer som indikerer at kvinner, og da særlig eldre kvinner, har høyere forekomst av bivirkninger enn menn (tabell 3). Denne forskjellen kan ikke alene tilskrives forskjell i forbruk av legemidler og levealder, men også kjønnsforskjeller i farmakokinetikk, interaksjon med perorale antikonsepsjonsmidler, samt kjønnsforskjeller i forekomst av sykdommer, bruk av helsevesenet og rapportering av bivirkninger.

Tabell 3. Mulige årsaker til forskjellig forekomst av bivirkninger hos menn og kvinner.

Biologiske/ fysiologiske årsaker

Ulik farmakokinetikk mellom kjønnene

Ulik farmakodynamikk (psykofarmaka) mellom kjønnene

Forskjeller i kroppens nivåer av sirkulerende hormoner

Bruk av perorale antikonsepsjonsmidler og hormonerstatningsterapi hos kvinner som kan interagere med andre legemidler som metaboliseres $i$ leveren

Kvinner bruker hyppigere legemidler og oftere flere legemidler samtidig Bruk av legemidler utvikles med tanke på effekt og sikkerhet hos menn

\section{Kulturelle årsaker}

Økt spontan bivirkningsrapportering hos kvinner

Intervjuundersøkelser om bivirkninger bedre tilrettelagt for kvinner? Menn bagatelliserer sine symptomer 
For å hindre unødig lidelse og kostnader for individet og samfunnet, er det viktig å forstå risikofaktorer for utvikling av bivirkninger for å hindre unødig lidelse og kostnader for individet og samfunnet. Kvinner bør inkluderes $\mathrm{i}$ fasene 1 og 2 i kliniske studier der den terapeutiske dose fastsettes, slik at dose kan tilpasses både kvinner og menns omsetning av legemidler. Økt forskningsinnsats på betydning av kjønn, alder og bruk av flere legemidler samtidig for utvikling av bivirkninger, samt oppfølgning fra helsemyndighetene, er nødvendig, særlig fordi stadig nye legemidler kommer på markedet og fordi tiden fra et legemiddel først testes på mennesker til det blir registrert stadig blir kortere.

\section{REFERANSER}

1. Kando JC, Yonkers KA, Cole JO. Gender as a risk factor for adverse events to medications. Drugs 1995; 50: $1-6$.

2. Harris RZ, Benet LZ, Schwartz JB. Gender effects in pharmacokinetics and pharmacodynamics. Drugs 1995; 50: 222-39.

3. Lewis-Hall F. Gender differences in psychotropic medications. Mt Sinai J Med 1996; 63: 326-9.

4. Kvinners helse i Norge. NOU 1999:13, vedlegg 8, 545-6.

5. Jämställd vård - Olika vård på lika villkor. Huvudbetänkande av Utredning om bemötande av kvinnor och män inom hälso- och sjukvården. SOU 1996: 133, 73-4.

6. Jensen SE. Lite forskning om det som skiljer könen åt. Läkemedelsvärlden 1998; 5: 34-35.

7. Levy M, Kewitz H, Altwein W, Hillebrand J, Eliakim M. Hospital admissions due to adverse drug reactions: a comparative study from Jerusalem and Berlin. Eur J Clin Pharmacol 1980; 17: 25-31.

8. Klein U, Klein M, Sturm H, Rothenbuhler M, Huber R, Stucki P, Gikalov I, Keller M, Hoigne R. The frequency of adverse drug reactions as dependent upon age, sex and duration of hospitalization. Int $J$ Clin Pharmacol Biopharm 1976; 13: 187-95.

9. Tran C, Knowles SR, Liu BA, Shear NH. Gender differences in adverse drug reactions. J Clin Pharmacol 1998; 38: 1003-9.

10. Schoenemann JH, Muller-Oerlinghausen B, Munther K-H, Enayati-Kashani S. Adverse drug actions (ADR) causing hospital admissions. J Pharmacoepidemiol Drug Safety 1998; 7: S1-S3.

11. Yassa R, Jeste DV. Gender differences in tardive dyskinesia: a critical review of the literature. Schizophr Bull 1992; 18: 701-15.

12. Spigset O. Adverse reactions of selective serotonine reuptake inhibitors. Reports from a spontaneous reporting system. Drug Safety 1999; 20: 277-87.

13. Martin RM, Biswas PN, Freemantle SN, Pearce GL, Mann RD. Age and sex distribution of suspected adverse drug reactions to newly marketed drugs in general practice in England: analysis of 48 cohort studies. $B r J C l i n$ Pharmacol 1998; 46: 505-11.

14. Simpson JM, Bateman DN, Rawlins MD. Using the Adverse Reactions Register to study the effects of age and sex on adverse drug reactions. Stat Med 1987; 6: 863-7.

15. Laake K, Kramer S, Nordal A, Borchgrevink CF. Bivirkninger som årsak til innleggelser i indremedisinsk akuttavdeling. Hvor godt er rapporteringssystemet? Tidsskr Nor Lageforen 1985; 105: 1792-5.

16. Moride Y, Haramburu F, Requejo AA, Begaud B. Under-reporting of adverse drug reactions in general practice. Br J Clin Pharmacol 1997; 43: 177-81.

17. Alvarez-Requejo A, Carvajal A, Begaud B, Moride Y, Vega T, Arias LH. Under-reporting of adverse drug reactions. Estimate based on a spontaneous reporting scheme and a sentinel system. Eur J Clin Pharmacol 1998; 54: 483-8.

18. Bivirkningsrapport for 1997. Nytt om legemidler 1998; 3: 55-8.

19. Raschetti R, Morgutti M, Menniti-Ippoloto F, Belisari A, Rossignoli A, Longhini P, La Guidara C. Suspected adverse drug events requiring emergency department visits or hospital admissions. Eur J Clin Pharmacol 1999; 54: 959-63.

20. Øydvin K (red.): Legemiddelforbruket i Norge i 1992-1996. Norsk medisinaldepot AS, Oslo 1997.

21. Svensk Läkemedelsstatistik 1996. Apoteksbolaget, Stockholm 1997.

22. Svarstad BL, Cleary PD, Mechanic D, Robers PA. Gender differences in the acquisition of prescribed drugs: an epidemiological study. Med Care 1987; 25: 1089-98.

23. Eggen AE. Patterns and predictors of drug use. A pharmacoepidemiologic study, linking the analgesig drug prescription to a population health survey in Tromsø, Norway. Thesis. Institute of Community Medicine, University of Tromsø, Tromsø, Norway, 1994. 
24. Eggen AE. The Tromso Study: frequency and predicting factors of analgesic drug use in a free-living population (12-56 years). J Clin Epidemiol 1993; 46: 1297-304.

25. Furu K, Straume B, Thelle DS. Legal drug use in a general population: association with gender, morbidity, health care utilization, and lifestyle characteristics. J Clin Epidemiol 1997; 50: 341-9.

26. Kampmann JM. Sovemedicin, nervemedicin og antidepressiva - kortlægning af forbruget i Danmark. Sundhetsstyrelsen, Lægemiddelafdelingen, København 1996.

27. Isacson D, Carsjo K, Haglund B, Smedby B. Psychotropic drug use in a Swedish community - patterns of individual use during 2 years. Soc Sci Med 1988; 27: 263-7.

28. Simoni-Wastila L. Gender and psychotropic drug use. Med Care 1998; 36: 88-94.

29. Dawkins K, Potter WZ. Gender differences in pharmacokinetics and pharmacodynamics of psychotropics: focus on women. Psychopharmacol Bull 1991; 27: 417-26.

30. Silvaggio T, Mattison DR. Setting occupational health standards: toxicokinetic differences among and between men and women. J Occup Med 1994; 36: 849-54.

31. Silverstein B. Gender difference in the prevalence of clinical depression: the role played by depression associated with somatic symptoms. Am J Psych 1999; 156: 480-2.

32. Linzer M, Spitzer R, Kroenke K, Williams JB, Hahn S, Brody D, deGruy F. Gender, quality of life, and mental disorders in primary care: Results from the PRIME-MD 1000 Study. Am J Med 1996; 10: 526-33.

33. Weissman M, Klerman G. Sex differences and the epidemiology of depression. Arch Gen Psychiatry 1977; 34: 98-111.

34. Kessler RC, Brown RL, Broman CL. Sex differences in psychiatric help-seeking: evidence from four largescale surveys. J Health Soc Behav 1981; 22: 49-64.

35. Wool CA, Barsky AJ. Do women somatize more than men? Gender differences in somatization. Psychosomatics 1994; 35: 445-52.

36. Verbrugge LM, Steiner RP. Prescribing drugs to men and women. Health Psychol 1985; 4: 79-98

37. Hohmann AA. Gender bias in psychotropic drug prescribing in primary care. Med Care 1989; 27: 478-90.

38. Morabia A, Fabre J, Dunand JP The influence of patient and physician gender on prescription of psychotropic drugs. J Clin Epidemiol 1992; 45: 111-6.

39. Gleiter CH, Gundert-Remy U. Gender differences in pharmacokinetics. Eur J Drug Metab Pharmacokinet 1996; 21: 123-8.

40. Legato MJ. Gender-specific physiology: How real is it? How important is it? Int J Fertil Womens Med 1997; 42: 19-29.

41. Makkar RR, Fromm BS, Steinman RT, Meissner MD, Lehmann MH. Female gender as a risk factor for torsades de pointes associated with cardiovascular drugs. JAMA 1993; 270: 2590-7.

42. Yonkers KA, Kando JC, Cole JO, Blumenthal S. Gender differences in pharmacokinetics and pharmacodynamics of psychotropic medication. Am J Psych 1992; 149: 587-95.

43. Vinge E. Män och kvinnor reagerar olika på läkemedel. Hormonellt betingade farmakodynamiska skillnader föga studerade. Läkartidningen 1998; 95: 3177-82.

44. Ereshefsky L, Saklad SR, Watanabe MD, Davis CM, Jann MW, Thiothixene pharmacokinetic interactions: a study of hepatic enzyme inducers, clearance inhibitors, and demographic variables. J Clin Psychopharmacol 1991; 11: 296-301.

45. Preskorn SH, Mac DS. Plasma levels of amitriptyline: effect of age and sex. J Clin Psychiatry 1985; 46: 276-7.

46. Lemmens HJ, Burm AG, Hennis PJ, Gladines MP, Bovill JG. Influence of age on the pharmacokinetics of alfentanil. Gender dependence. Clin Pharmacokinet 1990; 19: 416-22.

47. Hunt CM, Westerkam WR, Stave GM. Effect of age and gender on the activity of human hepatic CYP3A. Biochem Pharmacol 1992; 44: 275-83.

48. Loebstein R, Lalkin A, Koren G. Pharmacokinetic changes during pregnancy and their clinical relevance. Clin Pharmacokinet 1997; 33: 328-43.

49. Bologa M, Tang B, Klein J, Tesoro A, Koren G. Pregnancy-induced changes in drug metabolism in epileptic women. J Pharmacol Exp Ther 1991; 257: 735-40.

50. Schou M, Amdisen A, Steenstrup OR. Lithium and pregnancy. II. Hazards to women given lithium during pregnancy and delivery. $B M J 1973 ; 2$ : 137-8.

51. Kashuba ADM, Nafiziger AN. Physiological changes during the menstrual cycle and their effects on the pharmacokinetics and pharmacodynamics of drugs. Clin Pharmacokinet 1998; 34: 203-18.

52. Shenfield GM. Drug interactions with oral contraceptive preparations. Med J Aust 1986; 144: 205-11.

53. Walker JS, Carmody JJ. Experimental pain in healthy human subjects: gender differences in nociception and in response to ibuprofen. Anesth Analg 1998; 86: 1257-62.

54. Gear RW, Miaskowski C, Gordon NC, Paul SM, Heller PH, Levine JD. Kappa-opioids produce significantly greater analgesia in women than in men. Nat Med 1996; 2: 1248-50. 